\title{
THEORY OF PLANNED BEHAVIOR ON THE DETERMINANTS OF SMOKING BEHAVIOR AMONG ADOLESCENTS
}

\author{
Annisa Widya Panduwinata'), Bhisma Murti'), Pawito²) \\ ${ }^{1)}$ Masters Program in Public Health, Universitas Sebelas Maret \\ 2)Faculty of Social and Political Sciences, Universitas Sebelas Maret
}

\begin{abstract}
Background: Teenage smoking remains an important problem in Indonesia. This study aimed to determine factors associated with smoking behavior among adolescents using Theory of Planned Behavior.

Subjects and Method: This was an analytic observational study with a cross-sectional design. This study was conducted in Banjarnegara, Central Java, from October to November 2018. A sample of 200 adolescents was selected by random sampling. The dependent variable was smoking. The independent variables were intention, attitude, subjective norm, perceived behavior control, peer group, family intimacy, and media exposure. The data were measured by questionnaire and analyzed by a multiple logistic regression.

Results: Smoking behavior increased with strong intention to smoke (OR=4.53; 95\% CI=1.45 to $14.1 ; \mathrm{p}=0.009)$, strong peer group influence $(\mathrm{OR}=3.13 ; 95 \% \mathrm{CI}=1.16$ to $8.48 ; \mathrm{p}=0.025)$, and media exposure $(\mathrm{OR}=6.32 ; 95 \% \mathrm{CI}=2.29$ to $17.4 ; \mathrm{p}<0.001)$. Smoking behavior decreased with attitude $(\mathrm{OR}=0.26 ; 95 \% \mathrm{CI}=0.10$ to $0.64 ; \mathrm{p}=0.004)$, subjective norm $(\mathrm{OR}=0.15 ; 95 \% \mathrm{CI}=0.58$ to $0.40 ; \mathrm{p}<0.001)$, perceived behavior control $(\mathrm{OR}=0.17 ; 95 \% \mathrm{CI}=0.06$ to $0.46 ; \mathrm{p}=0.001)$, and strong family intimacy $(\mathrm{OR}=0.31 ; 95 \% \mathrm{CI}=0.12$ to $0.82 ; \mathrm{p}=0.019)$.

Conclusion: Smoking behavior increases with strong intention to smoke, strong peer group influence, and media exposure. Smoking behavior decreases with attitude, subjective norm, perceived behavior control, and strong family intimacy.
\end{abstract}

Keywords: smoking, adolescent, Theory of planned behavior

\section{Correspondence:}

Annisa Widya Panduwinata. Masters Program in Public Health, Universitas Sebelas Maret. Jl. Ir. Sutami 36 A, Surakarta 57126, Central Java, Indonesia. Email: annisawidya20@gmail.com. Mobile: +6285326744630 